ORIENTAL JOURNAL OF CHEMISTRY

An International Open Free Access, Peer Reviewed Research Journal

\title{
Increasing Stability of Cellulase, Obtained from Bacillus subtilis ITBCCB148 with Chemical Modification Using p-Nitrophenolcarbonate-Polyethylenglycol (NPC-PEG)
}

\author{
YANDRI ${ }^{*}$, PUTRI AMALIA,TATI SUHARTATI, MULYONO and SUTOPO HADI* \\ Department of Chemistry, University of Lampung, Bandar Lampung, Indonesia 35145 \\ ${ }^{*}$ Corresponding author E-mail: yandri.as@fmipa.unila.ac.id, sutopo.hadifmipa.unila.ac.id
}

http://dx.doi.org/10.13005/ojc/330547

(Received: April 07, 2017; Accepted: June 09, 2017)

\begin{abstract}
This research aims to increase the stabilty of cellulase obtained from local bacteria isolate Bacillus subtilis ITBCCB148 by chemical modification using p-nitrophenolcarbonate polyethylenglycol (NPC-PEG). The characterization of the native and modified enzymes were performed by determination of optimum $\mathrm{pH}$ and temperature as well as thermal stability. The result showed that the native enzyme has optimum temperature and $\mathrm{pH}$ is $55^{\circ} \mathrm{C}$ and 6 , respectively. The thermal stability test of native enzyme for $60 \mathrm{~min}$. at temperature of $55^{\circ} \mathrm{C}$ gave values of thermal inactivation rate constant $\left(k_{i}\right) \quad 0.035 /$ min., half-life $\left(t_{1 / 2}\right) 19.80 \mathrm{~min}$. and denaturation energy $\left.\Delta G_{i}\right)=$ $100.908 \mathrm{~kJ} / \mathrm{mol}$. The modified enzymes with modification degree of 63,70 and $81 \%$ have the same values of optimum temperature and $\mathrm{pH}$ as native enzyme, but their stability data have increased very significantly. Their $k_{i}$ values were $0.014 ; 0.012$ and 0.011 , respectively. Their $t_{1 / 2}$ values were 49.5; 57.75 and $63 \mathrm{~min}$., respectively; and their $\Delta \mathrm{G}_{\mathrm{i}}$ values were $103.407 ; 103.828$ and $104.065 \mathrm{~kJ} /$ mole, respectively. Thus, the chemical modification using NPC-PEG has shown to increase the enzyme stability of modified enzyme $2.5-3.2$ times compared to the native enzyme, although no change of optimum temperature and $\mathrm{pH}$ was observed
\end{abstract}

Keywords: B. subtilis ITBCCB148, celullase, chemical modification, NPC-PEG.

\section{INTRODUCTION}

The research on thermostable enzymes nowadays is so interesting due to their used in industrial developments especially in industries of detergent, production of glucose syrup from starch, synthesis of organic compound, paper and pulp, animal feed, the treatment of industrial wastes ${ }^{1}$. The thermostable enzyme work optimum at temperature at $60-125^{\circ 1}$. The research about this enzyme has been a hot topic as it is considered as the best way to study the protein stability.

Cellulase is an induction enzyme produced by microorganism in cellulose medium ${ }^{2}$. This enzyme works gradually in hydrolyzing cellulose to glucose ${ }^{3}$. Cellulase is widely used mainly in the enzymatic conversion of cellulose to 
glucose. In order to be applied in the industria process, cellulase must comply with some requirements, especially it can stand at extreme $\mathrm{pH}$ and temperature. Thus, enzyme with high stability must be obtained as in general is not stable at high $\mathrm{pH}$ and temperature 4 .

Enzymes with high stability and activity at extreme condition may be obtained by direct isolation from natural organisms which are found at this condition or by chemical modification to enzyme obtained from organism found in not extreme condition ${ }^{5}$. Mozhaev and Martinek ${ }^{6}$ stated that the enzyme stabilization of enzyme from mesofilic organism by chemical modification is a prefered way to obtain a stable enzyme.

In our previous researches, chemical modification to cellulase with low molecular weight modifiers, i.e. glyoxylic acid and dimethyla dipimidate have been performed ${ }^{7,8}$. The results showed that all modified enzymes have increased their stability compared to the native enzyme. In this paper, to increase the stability of cellulase obtained from local bacteria isolate $B$. subtilis ITBCCB148, the chemical modificatin using high molecular weight modifier, p-nitrophenolcarbonate polyethylene glycol (NPC-PEG) was carried out.

\section{EXPERIMENTAL}

\section{Materials}

All materials used in this research were pro analysis reagent and used without purification. Local bacteria isolate $B$. subtilis ITBCCB148 was obtained from Microbiology Laboratory, Chemical Engineering Department, Bandung Institute of Technology, Bandung, Indonesia.

\section{Research phases}

Research phases performed were production, isolation, purification and characterization of the purified (native) enzyme similar to the procedures previously reported ${ }^{9}$.

\section{Cellulase activity test and protein content determination}

The cellulase activity test was performed based on the Mandels method using dinitrosalycilic acid $^{10}$ and the protein content determination was performed based on the method by Lowry et al., ${ }^{11}$

The modification of native enzyme with $p$ nitrophenolcarbonate polythylenglycol (NPC-PEG) ${ }^{12}$

$10 \mathrm{ml}$ of native cellulase in $0.1 \mathrm{M}$ borate buffer pH 8 was added with NPC-PEG solid with variation of 5,10 and and $15 \mathrm{mg}$. The reaction mixture was magnetically stirred for $2 \mathrm{~h}$ at $4^{\circ} \mathrm{C}$.

\section{Determination of modification degree}

Determination of modification degree was done based on the method used by Synder and Sobocinski ${ }^{13}$ and as follows: $0.1 \mathrm{ml}$ of modified enzyme was dissolved into $0.9 \mathrm{ml}$ borate buffer $\mathrm{pH}$ 9.0) and then was added with $25 \mathrm{ml} 0.3 \mathrm{M} \mathrm{2,4,6-}$ trinitrobenzene sulfonic acid (TNBS). The mixture was then shaken and left it at room temperature for 30 minutes. The standard solution was made with the same composition but using the native enzyme, while the blank solution was made up of $1 \mathrm{~mL}$ borate buffer $0.1 \mathrm{M} \mathrm{pH} 9$ and $25 \mathrm{~mL} 0.3 \mathrm{M}$ TNBS. The absorbances were measured at the $I_{\text {max. }} 420 \mathrm{~nm}$.

\section{Characterization of enzyme before and after vmodification}

Determination of optimum temperature

The determination of optimum temperature was performed by varying the temperature at $45,55,60$, $65,70,75$ and $80^{\circ} \mathrm{C}$

\section{Determination of optimum pH}

Determination of optimum $\mathrm{pH}$ was performed by varying $\mathrm{pH}$ at $5 ; 5.5 ; 6 ; 6.5 ; 7 ; 7.5 ; 8$; 8.5 and 9.

\section{Determination of $K_{M}$ and $V_{\text {max. }}$}

The values of Michaelis-Menten $\left(\mathrm{K}_{\mathrm{M}}\right)$ and maximum reaction rate $\left(\mathrm{V}_{\text {max. }}\right)$ of the enzymes were performed by varying the concentrations of substrate (amylum solution) at $0.25 ; 0.5 ; 0.75 ; 1.0$; and $1.25 \%$.

\section{The thermal stability test of enzyme}

The thermal stability of native and modified enzymes was performed by measuring the residual activity of the enzyme after being incubated for 0 , $10,20,30,40,50$, and $60 \mathrm{~min}$. at temperature of $55^{\circ} \mathrm{C}^{14}$. 
Determination of half-life $\left(t^{1} / 2\right), \mathbf{k}_{i}$ and $\Delta \mathbf{G}_{i}$

Determination of $\mathrm{ki}$ value (thermal inactivation rate constant) of the enzyme was performed using the first order of inactivation kinetics equation (Eq. 1) ${ }^{15}$ :

$$
\ln \left(E_{i} / E_{0}\right)=-k i t
$$

The change of energy due to denaturation was performed using Equation $2^{15}$.

$$
D G_{i}=-R T \ln \left(k_{i} h / k B T\right)
$$

Table. 1: Determination of modification degree using TNBS

\begin{tabular}{lc}
\hline Sample & $\Delta \Delta_{420} \mathrm{~nm}$ \\
Modification & \\
\hline
\end{tabular}

(\%)

\begin{tabular}{lcc} 
Native Enzyme & .0 .5991 & 0 \\
Modification with & .0 .5867 & 63 \\
NPC-PEG 5 mg & & \\
$\begin{array}{l}\text { Modification with } \\
\text { NPC-PEG 10 }\end{array}$ & .0 .5853 & 70 \\
mgModifikasi dengan & .05834 & 81 \\
\hline NPC-PEG 15 mg & &
\end{tabular}

NPC-PEG $15 \mathrm{mg}$

\section{RESULTS AND DISCUSSION}

Chemical modifications of native enzyme with NPC-PEG were performed with 3 concentration variations at 5,10 , and $15 \mathrm{mg}$ (Table 1).

The determination of modification degree was based on the comparison of lysine residue before and after modification. Based on Table 1, the result of modification with NPC-PEG produced the modification degree of 63,70 and $81 \%$, respectively. The lysine residue on the native enzyme which was not modified with TNBS will form yellow complex, while on the modified enzymes, the unmodified lysine residu react with TNBS to form pale yellow complex. The more lysine residues modified, the less intense of the yellow complex observed.

\section{Determination of optimum temperature}

All modified enzymes with NPC-PEG have optimum temperature of $55^{\circ} \mathrm{C}$, the same value as the native enzyme. This finding can be expained that due to bulky molecular size of PEG, it was unable to enter the area heading to the site active of the enzymem as a result the three dimentional structure of the enzyme did not change so the activation energy also did not change.

This condition caused the optimum temperature did not change. The result is inline with assumption that the enzyme modification is only targeted occurred to $\mathrm{NH}_{2}$ group on the side chance of lysine on the surface of the enzyme. Kazan et al.,$^{15}$ and Francis et al. ${ }^{16}$ reported that chemical modification did not always cause the optimum temperature of the modified enzyme. Although no change on optimum temperature, however, the activity of the modified enzymes at higher temperature was better than that of the native enzyme, especially the modified enzymes at higher modification degree (70 and $81 \%)$. This is because the modification caused the enzyme rigidity increased, so the modified enzymes were more stand against temperature.

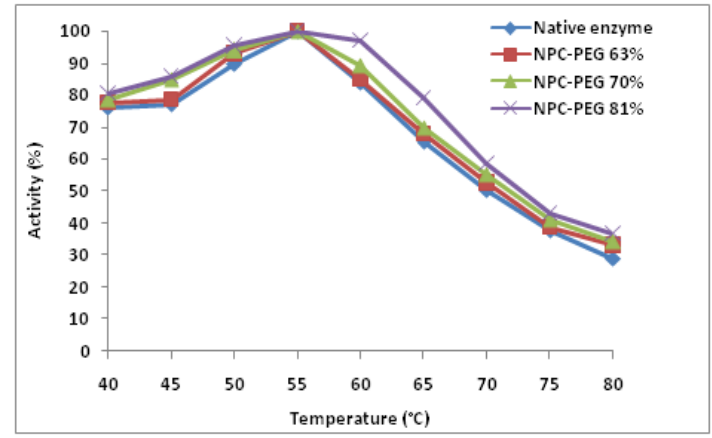

Fig.1.Optimum temperature of native enzyme and modified enzymes $(63,70$ and $81 \%)$

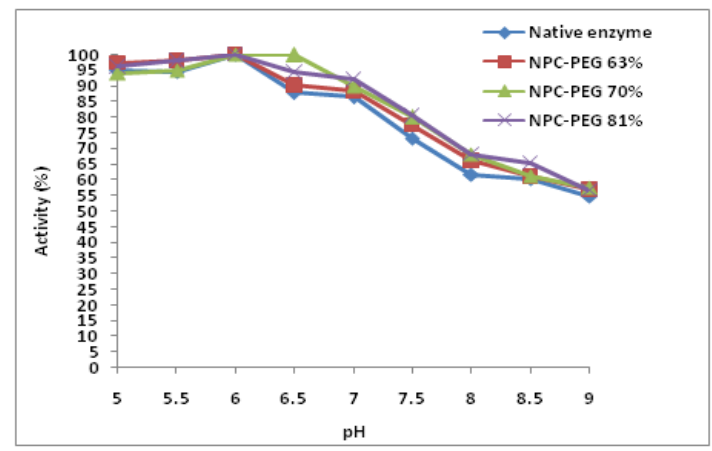

Fig. 2. Optimum pH of native enzyme andmodified enzymes (63, 70 and $81 \%)$ 


\section{Determination of optimum $\mathrm{pH}$}

There was no different observed for optimum $\mathrm{pH}$ for native and modified enzymes, i.e. at pH 6 (Fig. 2). The native and modified enzymes were stable at $\mathrm{pH}$ range of 5-8. Fig. 2 also showed that although optimum $\mathrm{pH}$ of modified enzymes did not change, however the modified enzymes have better activity compared to the native enzyme especially at $\mathrm{pH}$ range of 6.5 and 8.5 .

\section{Determination of $\mathrm{K}_{\mathrm{m}}$ and $\mathrm{V}_{\text {max }}$ Values}

Based on the Lineweaver-Burk equation, the $\mathrm{V}_{\text {max. }}$ and $\mathrm{K}_{\mathrm{M}}$ values of native enzyme were $10.101 \mathrm{imol} \mathrm{mL} \mathrm{m} \mathrm{min.}^{-1}$ and $3.878 \mathrm{mg} / \mathrm{mL}$ substrate, respectively. While the values obtained for all modified enzymes were $\mathrm{V}_{\text {max }}: 8.547 ; 8.403$ dan $9.615 \mathrm{imol} \mathrm{mL}^{-1} \mathrm{~min}^{-1}$, respectively; and $\mathrm{K}_{\mathrm{M}}: 3.188$; 3.327 and $4.096 \mathrm{mg} / \mathrm{mL}$ substrate, respectively. The determination result of $\mathrm{K}_{\mathrm{M}}$ values for native and all modified enzymes were not significantly different, this is predicted that no structural change occurred to the enzymes, mainly at the site active of the enzyme, so the enzyme afinity toward substrate also did not change.

The $V_{\text {max. }}$ values of all modified enzymes were decreased compared to the native enzymes, this is because the chemical modification with long chain NPC-PEG molecule on the surface of the enzyme made the enzyme was less flexible on aqueous solution ${ }^{14}$. PEG has also found to affect the enzyme proximity and orientation. Unmodified enzyme is easily able to interact with substrate, due to the present of long chain PEG molecule causing the condition around the enzyme is changed, so the $\mathrm{V}_{\text {Max. }}$ is decreased. . Kazan et al., ${ }^{15}$ and Francis et al., ${ }^{16}$ reported that chemical modification did not always cause the values of $\mathrm{K}_{\mathrm{M}}$ and $\mathrm{V}_{\text {Max. }}$ changed on the modified enzyme.

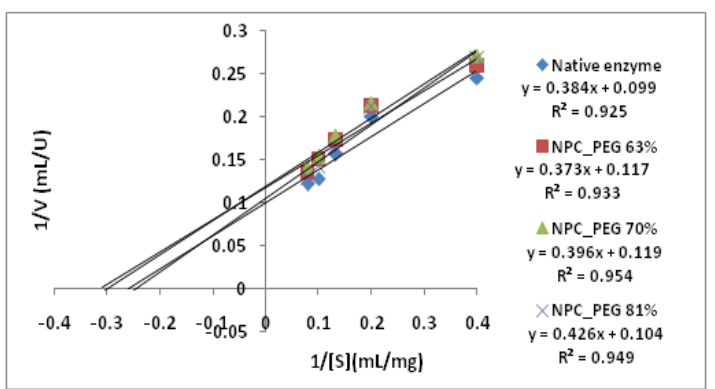

Fig. 3. The graph of Lineweaver-Burk of native enzyme and modified enzymes (63, 70 and $81 \%)$.

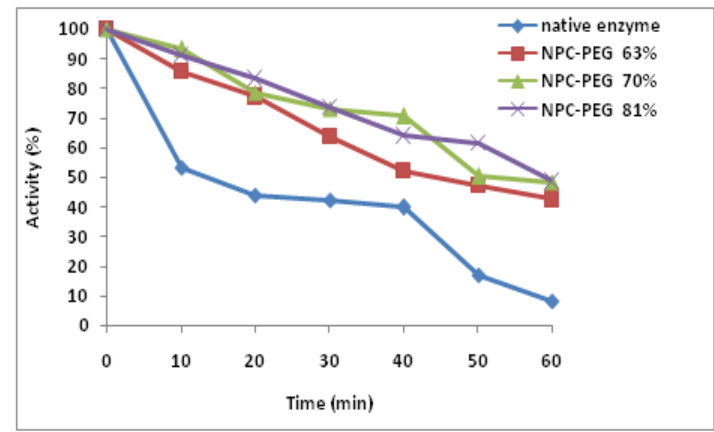

Fig. 4. Activity of the native and modified enzymes $(63,70$ and $81 \%)$ at $55^{\circ} \mathrm{C}$ vs time

\section{Thermal stability of the Enzyme}

As can be seen from Fig. 4 that \% residual acitivity of hative enzyme after being incubated at $55^{\circ} \mathrm{C}$ for $60 \mathrm{~min}$. was 8.071 , while the modified enzymes (63, 70 and $81 \%$ ) were $42.633 ; 48.415$ and 48.616 , respectively. The thermal stability of all modified enzymes with NPC-PEG were increased compared to the native enzyme (Fig. 4). All modified enzymes at different modification degree have halflife higher than that of native enzyme, thus the chemical modification has a good effect to the structure stability.

The mechanism of structure stability occurred to the cellulase due to chemical modification with activated PEG may be explained as follows: (1) the decrease of contact between the hydrophobic site and the solvent, since the wider of the hydrophobic site to contact with solvent will easily destabilize the enzyme structure; (2) the addition of hydrogen bond, as long chain of PEG may form hydrogen bond at the surface of the enzyme.

Modification of PEG to lysine residue exposed at the surface cause the hydropobic site at the enzyme surface is protected as a result its contact with solvent is decreased making the celluase structure is more desired.

Janecek and Balaz ${ }^{17}$ stated that the modification style with high molecular weight modifier such as PEG possibly made the modifiers to protect the hydrophobic site and prevent it to contact with water. PEG with molecular weight of 5000 is likely to follow this stabilization mechanism. 
Gaetner and Puigserver ${ }^{18}$ reported that the stability of trypsin modified with activated PEG was due to the formation of many hydrogen bonds on the enzyme structure caused by the long chain of PEG. This fact supported the result obtained in this work, the higher the modification degree, the higher enzyme thermal stability of the modified enzymes, and it is predicted that the numbers of hydrogen bond form are increased with the increase the modification degree.

Half-life $\left(t_{1 / 2}\right)$, thermal inactivation constant $\left(\mathbf{k}_{\mathrm{i}}\right)$, and denaturation energy change $\left(\Delta G_{i}\right)$

Rate of thermal inactivation constant $\left(\mathrm{k}_{\mathrm{i}}\right)$, Half-life $\left(t_{1 / 2}\right)$, and denaturation energy change $\left(\Delta G_{i}\right)$ are presented in Table 2.

All modified enzymes have increased their half-lives between two to three times compared to the native enzyme. According to Stahl ${ }^{19}$, thermal stability of enzyme is determined by determining the half life of the enzyme. The half life increased of the enzyme modified by NPC-PEG reported here similar to the result reported by other ${ }^{12}$.

The half-lives of cellulase modified by NPC-PEG with modification degrees of 63,70 and $81 \%$ have increased their half-lives $2.5 ; 2.9$ and 3.2 times respectively (Table 2 ). The result reported by Hernaiz et al., ${ }^{12}$ which modified lipase obtained from Candida rugosa using activated PEG with modification degree of 60 and $68 \%$ have increased the half-lives to 2.1 and 5 times.

The rate of inactivation thermal constant $\left(k_{i}\right)$ values for all modified enzymes were 2.5-3.2 times compared to the native one (Table 2). These data indicated that the rates of enzyme denaturation to the modified enzymes have decreased quite significant. In this work, the observation was performed to look at closely on the effect of chemical modification to the $\mathrm{k}_{\mathrm{i}}$ values of the modified enzymes with NPC-PEG. The decrease of $k_{i}$ values are predicted due to the bond formation between PEG long chain with $\mathrm{NH}_{2}$ group on side chain lysine residue on the surface of the enzyme molecule. This condition made enzyme less flexible in aqueous solution because of the protein unfolding became less, as a result the enzyme stability increased $^{14}$.

Table 2 also shows that the $\mathrm{DG}_{\mathrm{i}}$ of modified enzymes was increased significantly compared to the native one. The higher the modification degree, the higher $\Delta G_{i}$ obtained, this indicated that the modified enzymes were more rigid and less flexible,

Table. 2: The values of $k_{i}, t_{1 / 2}$, and $\Delta G_{i}$ of all enzymes

\begin{tabular}{lccc}
\hline \multicolumn{3}{c}{ Enzyme $\mathbf{k}_{\mathrm{i}}$ (min. $\left.^{-1}\right) \mathbf{t}_{\mathbf{1 / 2}}$ (minute) } & $\begin{array}{c}\Delta \mathbf{G i} \\
(\mathbf{k J / m o l})\end{array}$ \\
\hline Native & 0.035 & 19.80 & 100.908 \\
NPC-PEG 63\% & 0.014 & 49.50 & 103.407 \\
NPC-PEG 70\% & 0.012 & 57.75 & 103.828 \\
NPC-PEG 81\% & 0.011 & 63.00 & 104.065 \\
\hline
\end{tabular}

as a result the energy to denature the enzyme was also higher.

\section{CONCLUSIONS}

The chemical modification of native cellulase with p-Nitrophenolcarbonate-Polyethylenglycol (NPC-PEG) ha.

\section{ACKNOWLEDGMENTS}

The authors would like to thank The Directorate of Research and Community Services, The Ministry of Resarch, Technology and Higher Education, Republic of Indonesia that providing funds for this project to be undertaken through the Competency Grant Research Scheme (Penelitian Hibah Kompetensi) 2016 with contract number 79/ UN26/8/LPPM/2016, 13 April 2016.

\section{REFERENCES}

1. Vieille, C. and Zeikus, J.G. Tibtech.,1996, 3. Shiratori, H., Ikeno, H., Ayame, S., Kataoka, N., 14(6), 83-189.

2. Lee, S. M. and Koo, Y. J. Microbiol. Biotechnol. 2001., 11,229-233.

Miya, A., Hosono, K., Beppu, T. and Ueda, K. Appl. Environment. Microbiol., 2006, 72 (5), 3702-3709. 
4. Goddete, D.W., Terri, C., Beth, F.L., Maria, L., Jonathan, R.M., Christian, P., Robert, B.R., Shiow, S.Y., Wilson. C.R. J. Biotechnol.,1993, 28, 41-54.

5. Wagen, E.S. Strategies for Increasing The Stability of Enzymes, in Enzyme Engineering. The New York Academy of Sciences, New York.,1984, 7, 1-19.

6. Mozhaev, V.V. and K. Martinek. Enzyme Microb. Technol.,1984, 6(2), 50-59 .

7. Yandri, Rachmawati,R., Suhartati, T. and Hadi, S., J. Pure Appl.Microbiol., 2014, 8(5), 3675-3680.

8. Yandri, Amalia, P., Suhartati, T. and Hadi, S. Biosci Biotechnol. Res. Asia, 2015,12(3), 2089-2093 .

9. Yandri, A.S., Suhartati, T. and Hadi, S. Eur. J. Sci. Res., 2010, 39, 64-74 .

10 Mandels M., Raymond A. and Charles R., Biotech \& Bioeng. Symp. No 6. John Wiley \& Sons Inc., 1976.

11. Lowry O.H., Rosebrough N.J., Farr A.L. and Randall R.J., J. Biol. Chem.,1951, 193-269.

12. Hernaiz, M.J., Montero, J.M.S. and Sinisterra
J.V. Enzyme Microb. Tecnol.,1999, 24,181190 .

13. Synder, S.L. and Sobocinski, P.Z. Anal, Biochem., 1975, 64, 284- 288.

14. Yang Z., Michael D., Robert A., Fang X.Y. and Alan J.R., Enzyme Microb. Technol., 1996, 18, 82-89 .

15. Kazan D., Ertan H. and Erarslan A., Appl. Microbiol. Biotechnol.,1997, 48, 191-197.

16. Francis G.E., Delgado C. and Fisher D., PEG modified proteins in Stability of Protein Pharmaceuticals Part B (Ahern T J \& Manning M C, Eds), Plenum Press, New York,1992, 246-247.

17. Janecek, S. and Balaz, S. Febs Lett., 1992, 304(1), 1-3.

18. Gaertner, H. F. and Puigserver, A.J. Enzyme Microb. Technol., 1992, 14, 150-155 .

19. Stahl S., Thermophilic Microorganisms: The Biological Background for Thermophily and Thermoresistance of Enzymes in Thermostability of Enzymes (Gupta, M.N.editor), Springer Verlag, New Delhi, 59-60., 1999. 